University of St. Thomas, Minnesota

UST Research Online

\title{
$8-2015$
}

\section{Anti-social media: Executive twitter 'engagement' and attitudes about media credibility}

Michael C. Porter

University of St. Thomas, Minnesota, mcporter@stthomas.edu

Follow this and additional works at: https://ir.stthomas.edu/ocbmktgpub

Part of the Marketing Commons

This Article is brought to you for free and open access by the Marketing at UST Research Online. It has been accepted for inclusion in Marketing Faculty Publications by an authorized administrator of UST Research Online. For more information, please contact asle4660@stthomas.edu. 


\section{Emerald Insight}

\section{Journal of Communication Management}

Anti-social media: executive Twitter "engagement" and attitudes about media

credibility

Michael C Porter Betsy Anderson Mary Nhotsavang

\section{Article information:}

To cite this document:

Michael C Porter Betsy Anderson Mary Nhotsavang , (2015),"Anti-social media: executive Twitter "engagement" and attitudes about media credibility", Journal of Communication Management, Vol. 19 Iss 3 pp. 270 - 287

Permanent link to this document:

http://dx.doi.org/10.1108/JCOM-07-2014-0041

Downloaded on: 05 August 2015, At: 10:21 (PT)

References: this document contains references to 54 other documents.

To copy this document: permissions@emeraldinsight.com

The fulltext of this document has been downloaded 48 times since 2015*

\section{Users who downloaded this article also downloaded:}

Christopher Hendrik Ruehl, Diana Ingenhoff, (2015),"Communication management on social networking sites: Stakeholder motives and usage types of corporate Facebook, Twitter and YouTube pages", Journal of Communication Management, Vol. 19 Iss 3 pp. 288-302 http://dx.doi.org/10.1108/ JCOM-04-2015-0025

Weiting Tao, Christopher Wilson, (2015),"Fortune 1000 communication strategies on Facebook and Twitter", Journal of Communication Management, Vol. 19 Iss 3 pp. 208-223 http://dx.doi.org/10.1108/ JCOM-01-2013-0004

June Yung Kim, Jung Min Park, Jin Sook Im, (2015),"Relationship maintenance strategies on the Facebook pages of current US Senators", Journal of Communication Management, Vol. 19 Iss 3 pp. 224-238 http://dx.doi.org/10.1108/JCOM-11-2012-0089

Access to this document was granted through an Emerald subscription provided by emeraldsrm: 310770[]

\section{For Authors}

If you would like to write for this, or any other Emerald publication, then please use our Emerald for Authors service information about how to choose which publication to write for and submission guidelines are available for all. Please visit www. emeraldinsight.com/ authors for more information.

\section{About Emerald www.emeraldinsight.com}

Emerald is a global publisher linking research and practice to the benefit of society. The company manages a portfolio of more than 290 journals and over 2,350 books and book series volumes, as well as providing an extensive range of online products and additional customer resources and services.

Emerald is both COUNTER 4 and TRANSFER compliant. The organization is a partner of the Committee on Publication Ethics (COPE) and also works with Portico and the LOCKSS initiative for digital archive preservation. 
*Related content and download information correct at time of download. 
$\mathrm{JCOM}$

19,3

\section{0}

Received 11 July 2014

Revised 16 October 2014

Accepted 17 October 2014

\section{Anti-social media: executive Twitter "engagement" and attitudes about media credibility}

\author{
Michael C. Porter \\ University of St Thomas, Minneapolis, Minnesota, USA \\ Betsy Anderson \\ University of St Thomas, St Paul, Minnesota, USA, and \\ Mary Nhotsavang \\ University of St Thomas, Minneapolis, Minnesota, USA
}

\begin{abstract}
Purpose - The purpose of this paper is to take the results of two studies to hypothesize about practice and recommend research/debate on business leaders' use and perceptions of social media. Data were considered under the umbrella of current senior management practice, with the purpose to make suggestions for better practice, but primarily to theorize about the probable evolution of social media value and credibility for executives.

Design/methodology/approach - The first study presents results from a qualitative content analysis of Fortune and Inc. 500 CEOs' use of Twitter in terms of: activity and engagement; tweet subject matter; frequency of opinions expressed; and level of formality. The second considers the credibility of social media against traditional media and personal information sources within one quantitative survey.

Findings - Senior executives using social media (Twitter) tend to engage in one-sided conversations in a two-way medium. Further, most CEOs appear to be using more formal language than general Twitter users. These factors, combined with the low credibility and value of social media by senior managers, may indicate the best future hope for social media credibility with executives will be neutral. Practical implications - In examining a combination of current literature and the data from these separate studies, the authors posit a number of underlying challenges in realizing the potential of the evolving social media environment that may deserve specific research.

Originality/value - Discussion touches on implications for future adoption of social media tools by business leaders, as well as one-way vs two-way communication tendencies. This paper proposes a starting-point for theory development regarding this significant emerging area of communication.

Keywords Corporate communications, Information media, Communication management, Management accountability, Social media tools, Two-way communication

Paper type Research paper
\end{abstract}

\section{Introduction}

Pope Benedict XVI sent his first "tweet" on December 12, 2012. According to the New York Times that day, the Vatican indicated the pope would not follow anyone on Twitter, or retweet messages (Donadio, 2012). Since then, Pope Benedict resigned, and his successor, Pope Francis set up a Twitter account. As of March 2014, he had made nearly 300 Tweets and had almost 4 million followers, but was only following eight Twitter feeds - all of which appear to be language variations of his main account. The pontiff also uses formal tone and one directional messaging.

While the pontiffs communicate from a non-business perspective, as leaders of such a vast organization their visibility is similar to that of executives of large corporate entities. In an article published in 2012 titled, "140 Characters of Risk: Some CEOs Fear Twitter,"

the Wall Street Journal noted: "Many corporate leaders say they are too busy running a
Journal of Communication Management Vol. 19 No. 3, 2015 pp. $270-287$

(c) Emerald Group Publishing Limited 1363-254X

DOI 10.1108/JCOM-07-2014-0041 
company to spend time posting 140-character messages to Twitter, or re-tweeting posts from followers. What's more, for some companies, the business case for using the site can seem unclear, with no direct correlation between Twitter followers and sales" (Kwoh and Korn, 2012).

Even though the likes of Warren Buffett and Rupert Murdoch micro-blog, among the Fortune and Inc. 500 CEOs who had verifiable presences on Twitter at the time, less than one in 20 of their peers were doing likewise according to some studies (CEO.com/Domo, 2012). This remains true at the time of this research, in spite of the public visibility of social media, for better or worse, and the percolating influence of public relations practitioners to bring social media fully into the arsenal of corporate communication at all levels. Both articles cited above note the risks for organizations, including the inevitable "snarky" comments from readers who swarm to a tweet from trending topics or even followers, but also the downside of opening the firm to public bathing of corporate issues in the unfiltered flow of social media commentary.

Our research suggests the pontiffs are not alone as leaders engaging in a one-sided conversation via a two-way medium, and affirms some elements of senior leadership aversion to social media. In examining a combination of current literature and the data from two separate research efforts, the authors posit a number of underlying challenges faced in realizing the potential of the evolving social media environment that may deserve specific research.

The original purpose of the first study was an exploratory examination of the Twitter engagement of Fortune 500 and Inc. 500 CEOs to look for indications of best practices.

The second study was conducted by the first author in conjunction with the Minnesota Chapter of the Public Relations Society of America and Twin City Business, a magazine which maintains a predominantly senior management readership. As part of a "What Business Thinks" survey conducted in 2011, the magazine set out to take the pulse of senior managers in its metropolitan area on the subject of business information sources. The intention was to explore:

(1) How business leaders gather information from media and what they find credible?

(2) What does or does not earn consistent business audience consumption and credibility, given increased media options and changes in format/delivery of traditional media?

(3) The value executives place on social media voices.

The results of both efforts provided insights about the original research questions, and for the purpose of this paper these data offer perspective for additional analysis and conclusions about senior executive behavior regarding social media for business purposes. When considered with the additional context of the following literature, questions arise related to: the dominance of one-way communication by senior leaders in a channel considered by them to be less than credible; corporate leaders use of language when using Twitter specifically that is generally more formal than is predominant in the medium; and whether the best future hope for social media credibility with senior leaders is mediocrity.

\section{Literature review}

\section{Practitioner perceptions}

The perceptions of social media among practitioners range from those who fully embrace its various channels and potential benefits to those who are more cautious of 
JCOM 19,3

272

potential pitfalls. As might be expected of any group of enthusiasts for progressive tools, in seeking industry leadership public relations practitioners represent early adopters of emerging social media tools such as blogs to target publics more effectively (Porter et al., 2007). Measuring success and balance may, however, be problematic. A content analysis of PRSA's Public Relations Tactics suggests that the claims of social media power may significantly outweigh available evidence of its effectiveness as a communication tool (Taylor and Kent, 2010). Although advancements in quantifying social media continue to offer considerable promise, promoting the use of social media tactics in practice remains largely based on the practitioner perceptions of the power of social media and individual enthusiasm over its implementation.

According to work by Diga and Kelleher, this is not simply about the "power" or utility of the channel, but that knowledge and application of social media deliver perceived increases in power of practitioners at various levels within their organizations. Whether related to enhancing influence in current positions, being seen as an expert, or increasing overall prestige, this work suggests a relationship between social network affinities and perceived power in these areas (Diga and Kelleher, 2009). The authors further suggest their work corroborates the findings of Porter and Sallot (2005), who found that public relations practitioners perceived that their generalized online engagement had enhanced personal organizational power/status.

Ironically, even though two-way symmetrical communication has long been acknowledged as foundational to the practice of excellent public relations, Roper (2005) has suggested that for mega-organizations (such as Fortune/Inc. 500 firms) the practice may actually be a means to maintain hegemonic power.

Others have found that social media presents common challenges for practitioners and executives related to accepting the lack of control associated with social media. Social media engagement may expose companies to internal and external risks, from intellectual property leaks and management critique internally to blatant attacks externally. Meanwhile, some practitioners involved cited skepticism in their organizations about the value of social media, in addition to lack of understanding about how to actually use social media tools strategically (DiStaso et al., 2011).

The preceding should be considered within the context of the general advances in understanding of public relations practice from both theoretical and practical perspectives. New measures by which public relations practitioners can plan, monitor, and evaluate campaigns and ongoing programs for clients and employers help manage knowledge and expertise of public relations practitioners and departments, but more importantly, the expectations the generalized aggregate of corporate leaders (Laskin, 2012). Further, it has been strongly suggested that public relations contributes to societies in previously undocumented ways, building relationships that not only create social capital, but may enhance the development of democracy (Yang and Taylor, 2013) and within power structures that generally go unrecognized (Edwards, 2006). While these advances occur, the ongoing discussions about public relations practice as a "true" profession continue among practitioners, academics, and business leaders. The conversation, regardless of the data source comes back to the necessity of finding common ground among these groups and commitment to developing standardized, universal forms of public relations practice (Abdullah and Threadgold, 2008). This area of inquiry becomes relevant to this work in that the evolving nature of the craft makes the legitimacy of social media in the minds of business leaders and their use of these channels will directly impact the progress of public relations practice on its path toward professional recognition. 
Even though more than half of American adults used a social networking site of some sort in 2012 (CEO.com, 2012), as is relevant to the second study presented in this analysis, media practitioners continue to give traditional media higher grades for accuracy, credibility, and ethics than social media or blogs (Wright and Hinson, 2010).

However, significant evidence exists that social media engagement tends to be less about establishing dialogue with social media voices or audiences than as a new platform to trumpet organizational messaging. For instance, after analyzing more than 4,500 tweets, one study found that the nation's largest non-profits failed to use Twitter to maximize stakeholder involvement. Rather, the platform supports a one-way communication channel, with less than 20 percent of total tweets demonstrating conversations and about 16 percent showing indirect connections to specific users (Lovejoy et al., 2012).

Additionally, early evidence revealed that only 35 percent of Fortune 500 companies used Twitter, with only 24 percent of those being actively engaged (Barnes and Mattson, 2010). Content analysis of corporate tweeting established that such accounts blended customer testimony, complaints, and product/service inquiries (Jansen et al., 2009). One-way communication remains the dominant form of messaging used by organizations on Twitter (Waters and Jamal, 2011; Xifra and Grau, 2010). Chasing followers who want to receive one-way messages has become a common non-communication strategy (Rybako and Seltzer, 2010). Further, organizations have been cautioned to venture carefully into social media because slim evidence exists that such efforts can actually build communities around organizations (Kent, 2008). Other research suggests that individuals remain apathetic regarding organizational use of social media since people primarily use the social media services to connect with friends, family, and co-workers (Vorvoreanu, 2009).

Freberg et al. (2011) suggest the concept that real engagement comes from social media influencers (SMIs) generating social capital in their space, akin to the additional goodwill contributions to the bottom line attributed to the chief executive officer of a firm (Gaines-Ross, 2003). These authors proposed analogous "SMI capital" exists: "To maximize organizational SMI capital requires methods that provide precise information about relevant influencers and how they are perceived by Audiences" (Freberg et al., 2011). To that end, Dutta writes in the Harvard Business Review:

Today's leaders must embrace social media for three reasons. First, they provide a low-cost platform on which to build your personal brand, communicating who you are both within and outside your company. Second, they allow you to engage rapidly and simultaneously with peers, employees, customers, and the broader public, especially younger generations, in the same transparent and direct way they expect from everyone in their lives. Third, they give you an opportunity to learn from instant information and unvarnished feedback. Active participation in social media can be a powerful tool - the difference between leading effectively and ineffectively, and between advancing and faltering in the pursuit of your goals. You can use this tool proactively, as Dickson did, or reactively, as the technology CEO could have done (Dutta, 2010).

Measurement of "engagement" is problematic at best, and assessment of perception of the content and learning even more so. Gilpin et al. (2010) suggest, "It seems reasonable to conclude that, unless comments are used to expressly challenge the communicators, posting a comment on a blog suggests at least partial acceptance of its authenticity." This might translate similarly to re-tweets and hashtags.

\section{Value propositions}

In order to contrast social media with traditional media and social networks, our second set of data represent how much confidence senior managers place on information from 
JCOM 19,3

those sources. While the vast majority of recent literature in these three areas focusses on general audiences and/or mainstream media sources rather than those aimed primarily at business topics, such literature can be used to provide context for investigation and analysis of how business people consume media and regard information sources.

\section{$274 \quad$ Value of traditional media information}

The general public's trust in traditional news sources had been steadily declining. Pew Research Center surveys, for example, revealed that the percent of the public who gave their daily newspaper low credibility ratings nearly tripled between 1985 and 2005 - from 16 to 45 percent. Public trust in television broadcasts and leading news magazines also fell (Doherty, 2005). For example, the percent of survey respondents who said they could trust little of what they saw on ABC News grew from 13 percent in 1985 to 36 percent in 2004. Similarly, those who said they could trust little of what they read in Newsweek increased from 15 to 37 percent over the same two decade period (Pew Research Center, 2005). Kiousis (2001) found that online news credibility ranks somewhere between that of newspaper coverage and television news. A random sample of Austin, Texas, residents gave online news a 2.06 rating (measured using a 0-4 Likert scale, where higher scores indicated higher credibility).

Media scholars have commented on the potential impacts of the public's declining confidence in news media sources. Doherty (2005) reported that "journalists believe that the loss of public trust is a leading cause of declining news audiences," according to a 1999 Pew Research Center survey (p. 48). Interestingly, the 2013 Edelman Trust Barometer reports that 57 percent of global survey participants trust media generally, which is an increase of five points over the previous year. The fact that those in emerging countries have significantly more trust in media than those in developed nations may account for this trend that differs from much of the academic literature focussed on trust in the USA.

\section{Value of social media information}

It is important to understand the degree to which people in general trust online social media information. As Sweetser et al. (2008) noted, "with the ever-increasing number of online information sources, credibility has taken the stage to separate the good from the bad." (p. 169). In terms of traditional vs social media, 58 percent of respondents in developed countries trust traditional media, whereas only 26 percent trust social media (Edelman, 2013). Predictably, trust in social media increases among younger (global) audiences, however, with 47 percent of $18-29$ year-olds trusting social media vs only 29 percent of those 65 and older (Edelman, 2013). In terms of specific social media channels, Forrester Research reports that only 15 percent of Americans trust posts by companies or brands on social networking sites like Facebook and Twitter (whereas 70 percent trust brand or product recommendations from family and friends) (Wasserman, 2013).

Other than commercial research such as the Edelman and Forrester surveys reported in popular media, only a small, emerging area of academic research concerns the credibility of Web 2.0 social networks (e.g. Twitter, Facebook, blogs, LinkedIn), with most of the literature in this area focussing on blogs. Among the general public, a 2005 survey found that 57 percent of respondents distrust information read on blog sites (Consumer Reports Web Watch, 2005).

However, several studies indicate that those who read blogs regularly believe the content to be more credible than those who are not regular blog readers (e.g. Johnson et al., 2007; Sweetser et al., 2008). For example, Johnson et al. (2007) surveyed blog readers 
specifically, and found that nearly three-fourths of them rated blogs as moderately to very credible. Additionally, specific groups may perceive blogs to be more credible than the general public. Johnson et al. (2007), for example, found that politically interested internet users rated blogs as the most credible of all media (followed by traditional and online newspapers, online cable TV news, traditional cable TV news, online television news, and finally, traditional television news).

Schmierbach and Oeldorf-Hirsch $(2010,2012)$ studied the credibility of Twitter using the exact same information presented in different formats. They found that participants rated a clearly identified New York Times tweet with a story link as less credible than same information presented as a New York Times story rather than distributed through a tweet. A follow-up experiment, which assigned participants to the either the tweet, New York Times story, or a third condition where a blog linked to the New York Times story, found similar results. Credibility scores were highest for the New York Times, and lowest for Twitter. Interestingly, the Twitter manipulation in the first experiment said, (posted) "about one hour ago from web," whereas the tweet in the second experiment said, (posted) "about 14 hours ago from Web," which could further erode credibility, given that one expectation and strength of Twitter as a medium is timeliness of information delivery. To this end, Westerman et al. (2014) directly studied whether higher credibility was associated with how recently tweets were posted by having participants rate the credibility of tweets they viewed in one of three conditions: posted one minute ago, one hour ago, or one day ago. The researchers did not find the expected linear relationship: the one minute ago tweets were rated as the most credible, followed by the one day ago tweets. The one hour ago tweets were rated least credible. However, they did find that tweet recency was associated with cognitive elaboration, in that the more timely the tweet, the more participants gave it careful thought.

\section{Study 1}

\section{Method regarding CEO Twitter activity}

The purpose of the first study was to investigate CEO engagement on Twitter. Publicly available lists of 2011 Fortune 500 and Inc. 500 companies were obtained via Fortune magazine and $I n c$. magazine web sites. Included with the Fortune 500 company list were the names of the current CEOs, but the Inc. 500 company list did not disclose CEO information, so names were collected from company web sites. A search on the Twitter web site was conducted using each CEO's name as the keyword to find whether a Twitter account existed. If an account was not found using the search function on the Twitter web site, a Google search was conducted to check for a Twitter account using keywords that included the CEO's name and the word "Twitter." This proved to be an effective supplement to a search on the Twitter web site, as several additional accounts were identified through this method. The following information was collected for CEOs who had Twitter accounts: number of followers, number of total tweets, and all tweets from January through March of 2012. If a CEO had a Twitter account but did not tweet during the determined time frame, then the number of followers, number of total tweets, and date of last tweet were recorded (content of tweets prior to January 2012 was not analyzed).

The frequency of tweets was recorded to determine the level of CEO engagement/ activity on Twitter. Frequency was categorized into five groups:

(1) very active: at least one tweet per day;

(2) active: at least one tweet per week; 
$\mathrm{JCOM}$

19,3

276

(3) somewhat active: at least one tweet per month;

(4) rarely active: one to three tweets between January and March; and

(5) inactive: no tweets between January and March.

Each CEO was then placed in one of the five groups to draw comparisons between Fortune 500 and Inc. 500 CEO engagement levels.

In order to compare content and subject trends between Fortune 500 and Inc. 500 CEOs, a qualitative analysis of each original tweet was conducted using a manual coding system. For purposes of this research, a tweet was considered original if it did not include an "RT" or an @twitterhandle within the tweet. Because of the high volume of tweets for several of the CEOs, the number of re-tweets and replies were noted, but content of re-tweets and replies was not analyzed.

As there was no reasonable way to validate otherwise, tweets were assumed to be created and sent by the CEOs personally. As the owners of the Twitter account, any posting must be sanctioned in tone and content by the respective corporate leader, even if the effort of an executive assistant, employee in the communications/marketing department or professional agency was being used. In the same way one would accept a CEO quote in a corporate press release as attributed in the document, each tweet was treated as representative of the voice chosen by the CEO who owned the Twitter account.

The basis of the analysis was conducted using the manual coding system pictured in Figure 1.

In instances where a tweet may have multiple codes, the overarching theme of each tweet was determined and coded as such. For example, many tweets included an opinion about an industry trend or general news topic. However, if the tweet included a link to an article, it was coded as industry or news, depending on the topic. After tweet coding, the number of tweets in each code was tallied and recorded for individual CEOs

Corporate: Tweet mentions company name and/or links to content on company website or news articles about company

Industry: Tweet discusses trends relevant to the industry of the company and/or links to industry articles/publications

Business: Tweet discusses general business news outside of the industry of the company and/or links to articles

Opinion/Comment: Tweet expresses opinion/thoughts about a product, trend current event, or other topic of personal interest and does not include a link to an article or website link to an article or website

News: Tweet highlights general trending news topics that are not business or industry related and includes links to articles

Event/Tradeshow: Tweet mentions event or tradeshow name and discusses key highlights from event/tradeshow

Figure 1.

CEO tweet manual coding system
Personal: Tweet mentions events and/or includes photos from personal life, FourSquare check-ins, Pinterest posts and game results such as Words With Friends

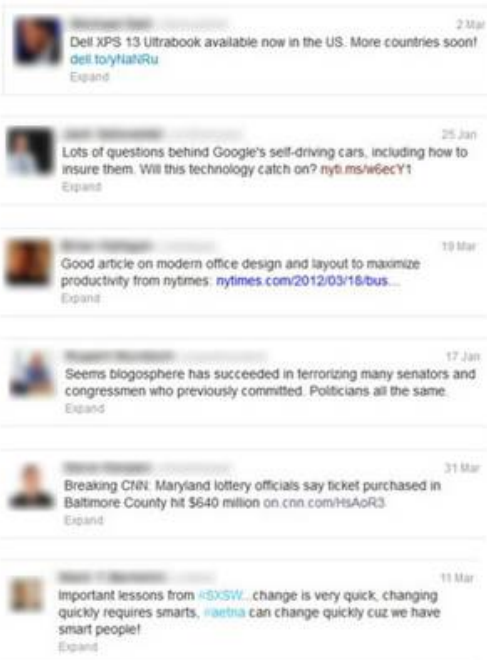

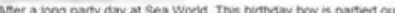
Happy birthday, Huddo instagr ampitucatubom 
to determine popular tweet categories and whether similarities and differences existed between Fortune 500 and Inc. 500 CEO tweet content (news trends that occurred during January through March were also noted and, if tweeted by a CEO, highlighted during media the analysis and coding process).

Finally, tweets were evaluated based on: length of tweet determined through word count; use of colloquial language; and punctuation. Colloquial language included: gonna; awesome; WTF; sweet; bummed; other similar slang terms; and use of foul language. Punctuation was evaluated based on the excessive use of exclamation points and emoticons using punctuation symbols. Tweets that included colloquial language were highlighted and tallied for each CEO. The goal of calculating average word count and colloquial language use was to discover style patterns of Fortune 500 and Inc. 500 CEO tweets.

\section{CEO tweet frequency results}

Only 3.2 percent of Fortune 500 CEOs have a Twitter account compared with 17 percent of Inc. 500 CEOs with Twitter accounts. It was not surprising to find a larger number of Inc. 500 CEOs have Twitter accounts, given the contrasting levels of size, wealth, and risk with Fortune 500 CEOs.

These results are in line with CEO.com/Domo research conducted only on Fortune 500 CEO Twitter engagement in May 2012, which did not include any content analysis (CEO.com/Domo, 2012).

While more Inc. 500 CEOs have Twitter accounts, 30 out of the 87 with accounts (34.5 percent) did not tweet between January and March. In fact, a higher percentage of Inc. 500 CEOs did not tweet at all within the three-month time frame compared to the percentage of those who tweeted at least once per day (34.5 vs 23 percent). This may indicate that many Inc. 500 CEOs were early adopters of Twitter, but did not maintain engagement on Twitter. Of the Inc. 500 CEOs who did not tweet between the specified time frame, more than half (66.7 percent) have not tweeted since 2011, two have not tweeted since 2010, two since 2009, and two have not sent out a single tweet.

The activity levels of Fortune 500 CEOs were more black and white, meaning they were either very active or inactive. Nearly 38 percent of Fortune 500 CEOs tweeted at least once a day while 31.25 percent did not tweet between January and March (Figure 2).

\section{CEO tweet content analysis}

Not including the CEOs of both groups who did not tweet between January and March, 73 percent of Fortune 500 CEOs vs 50 percent of Inc. 500 CEOs focussed a majority of
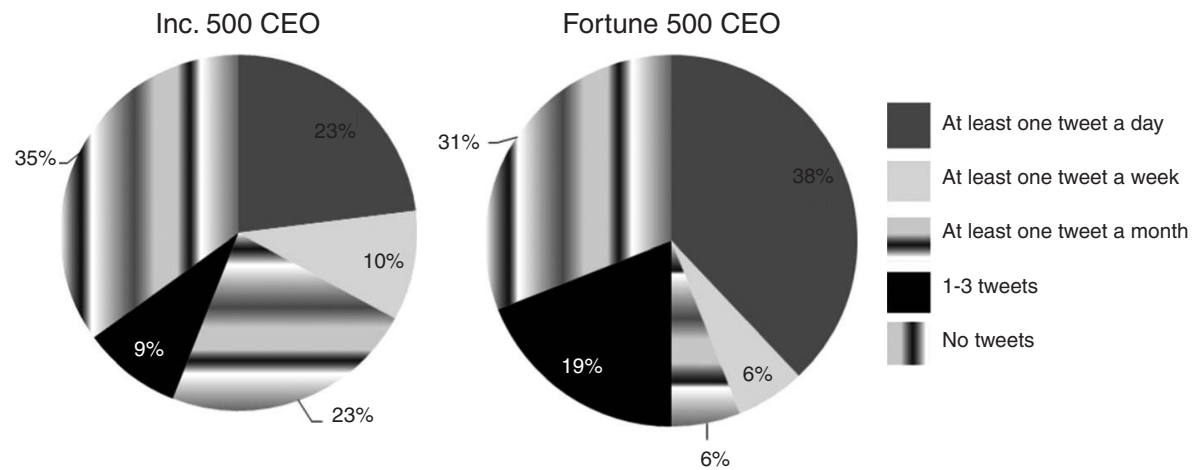

Figure 2. CEO Twitter activity (January-March 2012) 
$\mathrm{JCOM}$

19,3

278

Figure 3.

Fortune CEO

"company"

tweet exemplars

Figure 4.

Inc. CEO "Company" tweet exemplars

tweets on company news and mentions. When tweeting about their companies, Fortune 500 CEOs kept tweet topics at a very high level such as: highlighting news articles about the company; posting links to the company web site to generate traffic; and recognizing employees for great work (Figure 3).

Inc. 500 CEO tweets about their companies varied including: financial mentions touting growth success; general sentiments about the company; and job opportunities. Inc. 500 CEOs often included personal thoughts and/or opinions with company tweets (Figure 4).

Despite the fact that more Fortune 500 CEOs tweeted about their companies than the Inc. 500, the majority of total tweets among all Inc. 500 CEOs were corporate (39 percent) while the majority of tweets among Fortune 500 CEOs were opinion/commentary (41.7 percent). Rupert Murdoch, CEO of News Corp., skew much of these data, as his tweets comprised 28 percent of total Fortune 500 CEO tweets and were mainly opinion/ commentary (96 percent).

The few times the CEOs categorized as "Not Very Active" or "Inactive" tweeted, the content was mainly focussed on the company. Given their low level of Twitter activity, it is no surprise that each tweet would be maximized to promote the company rather than focus on industry trends or popular news topics. Even though they tweet infrequently, the "Not Very Active" CEO Twitter accounts still maintain more than 300 followers each. This number did not remotely compare with the more active CEO Twitter accounts that garnered more than 10,000 followers in most cases.

While general news topics did not comprise a large percentage of total tweets among the CEOs in either group, trends did exist regarding popular topics mentioned. Trending news topics during the three months included the New Year, Super Bowl, Grammys, March Madness, and Linsanity (referring to Jeremy Lin's sudden popularity in the NBA). SOPA and Republican/Democrat presidential nominees were also popular topics among

Dell Quick Resource "QR Locator puts :PowerEdge support in the

hands of server admin dell torWL.6VE.F

Expand

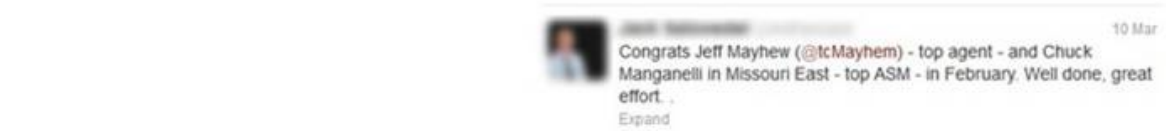

Supervalu builds on commitment to source sustainable seatood.

phoenix corporate-if netiphoenox zhtmi?

Expand

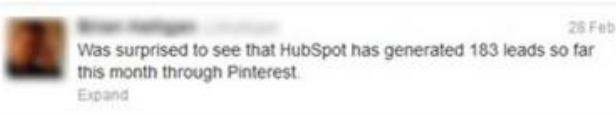

this month through Pinterest

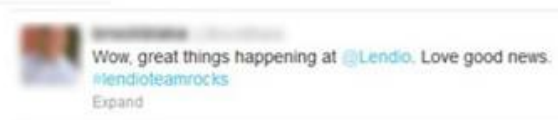

We're looking for awesome BD folks in NYC eclearspring!

clearspring comabout/careers?

Expand 
Inc. 500 CEOs. Fortune 500 CEOs chose not to disclose political views in their tweets, possibly due to the risk of alienating investors and shareholders and the potential backlash to company financials by aligning with a political candidate and/or party.

Less than 2 percent of total tweets by Fortune 500 CEOs included colloquial language such as "cool" or "awesome." In fact, most of their tweets were complete sentences using proper grammar and punctuation. Word usage was also more business-oriented than Inc. 500 CEO tweets, which were shorter and less formal. Nearly 4 percent of total tweets by Inc. 500 CEOs contained some form of colloquial language, several even used expletives (Figure 5).

Clearly Fortune 500 and Inc. 500 CEOs differ in their Twitter content and language use, which may be attributed to their contrasting audiences and company brand images. However, both groups had a larger number of CEOs that focussed on corporate content and an equally large number of CEOs that tweeted their opinions/commentary. Also, the more actively engaged CEOs were on Twitter, the more followers they tended to have, which suggests that some stakeholders are eager to get insights from the people at the top. While there did not appear to be clear strategies in terms of balancing content across a broad spectrum, there appeared to be strategic uses of tweets for enhanced engagement and search such as hashtags (the \# symbol used to mark keywords or topics in a tweet and categorize those tweets to help them show up more easily in a Twitter search), links, and mentions (a tweet that contains an @username). Yet, few of CEOs seemed overly self-promotional or overtly bent on pushing marketing and brand messages.

\section{Study 2}

\section{Senior manager media perceptions}

The second study explored business managers' opinions of social media and other information sources in terms of perceived value and credibility. A questionnaire was developed in conjunction with the editorial staff of (City Blinded for Review) Business magazine as the publication's eleventh "What Business Thinks" survey. The final instrument included 21 questions, both quantitative and qualitative in nature, and was deployed using Qualtrics software. An electronic invitation from the magazine publisher stated:

This year's topic, 'Who Are Your Reliable Sources,' looks at where you go for business intelligencewhich sources of information you use and trust as new media and social media proliferate alongside traditional media and your own personal network in the business community [...] This online survey is confidential and takes most people 10 minutes to complete (we tested).

The letter included a link to the survey and was sent by the publication to all of the magazine subscribers for whom e-mail addresses were on file (14,261 individuals), of whom 487 responded (3.41 percent). This sample size is about double that of many public relations surveys with 100-250 respondents (e.g. Johansen et al., 2012; Meng et al., 2012; Tallapragada et al., 2012; Shin et al., 2011). It also represents a unique population of business executives to add to the voices of professionals who are most often surveyed for communication

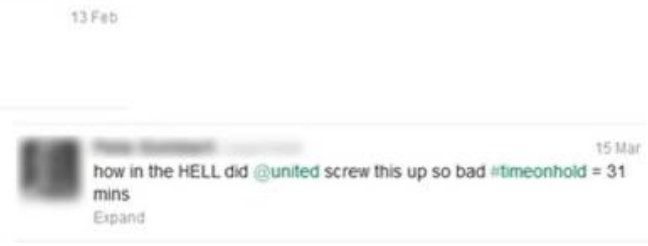

Figure 5. CEO tweet "expletive" exemplars 
JCOM 19,3

280

research. While the response percentage itself was small, a number of researchers have suggested that in dealing with business executives, the expectations of engagement must be lowered, if for no other reason than the demands on their time in running business (Cycyota and Harrison, 2002), and others suggest that the representativeness of these populations may mitigate response rate (Cook et al., 2000).

The survey participants did indeed appear to be generally representative of magazine subscribers. Approximately 75 percent of participants self-identified as working in senior management roles (slightly higher than the BPA Publisher's Statement[1] of June 2010 for the percentage of "top management" - 70 percent - receiving print circulated issues of the publication). While other demographics of participants closely paralleled general readership, female participation in this survey was 11 percent higher than in audits (39 vs 28 percent). Descriptive statistics of the respondents can be found in the Appendix.

The history of the "What Business Thinks" survey as an annual feature may in part explain why more than 97 percent of those who began the survey completed the instrument. While the university offered survey participants a chance to win free admission to one of its executive education programs (which otherwise costs $\$ 3,000$ ), only about a quarter of the participants elected to register at the end of the survey.

\section{Executive media confidence}

When considering the data gathered from the "What Business Thinks" survey, the core of the material indicated that readers of the publication generally put the most trust in information/perspective from colleagues inside their current organizations and peers outside those organizations. Confidence in traditional print/broadcast media channels and associated online extensions hovered just above neutral. When looking at social media provided a comparable neutral value for the LinkedIn community, but a significant degree of skepticism (see Table I below) about the credibility and value of blogs, Facebook and Twitter. However, blogs did fare slightly better than other Web 2.0 channels.

To determine whether the differences in how much trust and value managers placed in various sources of information were statistically significant, the sources were first grouped together into three categories: social media (LinkedIn, Twitter, Facebook, and blogs), traditional media (local and national newspapers, magazines, television news, and radio news), and personal networks (colleagues inside the organization and peers outside

Rate the value

to you in a

business context ${ }^{\mathrm{a}}$

\begin{tabular}{lccccccccc}
\hline & LinkedIn & Twitter & Facebook & Blogs & & & & \\
Trustworthiness & 3.11 & 2.01 & 2.2 & 2.46 & & & & \\
Information value & 2.94 & 2.02 & 2.15 & 2.63 & & & & \\
& National & Local & National & Local & National & Local & National & Local \\
& newspapers & newspapers & magazines & magazines & TV & TV & radio & radio \\
& & & & & news & news & news & news \\
Trustworthiness & 3.55 & 3.47 & 3.49 & 3.6 & 3.12 & 3.28 & 3.43 & 3.39 \\
Information value & 3.68 & 3.55 & 3.49 & 3.62 & 3.2 & 3.19 & 3.44 & 3.33 \\
& Colleagues & Peers & & & & & & \\
& inside & outside & & & & & & & \\
Trustworthiness & organization & organization & & & & & & &
\end{tabular}

Table I.

Executive trust and value of information sources

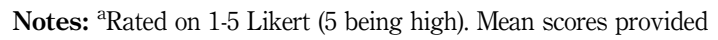


the organization). Multivariate analysis (MANOVA) compared whether the two dependent variables (trust and information value) varied based on the type of information source (social media, personal networks, and traditional media).

Results indicated statistically significant differences in the amount of trust and information value managers placed in different information sources (see Table II). Further analysis was conducted to determine which information sources differed with one another based on perceived trust and information value. Post hoc comparisons (using Bonferroni adjustment) found social media sources to be the least trustworthy $(M=2.44)$, followed by traditional media $(M=3.42)$. Personal network sources of information were the most trustworthy $(M=4.42)$. Similarly, managers placed the least information value on social media sources $(M=2.43)$, followed by traditional media $(M=3.44)$. Personal network sources of information were the most valued $(M=4.34)$.

These results are similar to those found in other studies and popular media articles, with personal contacts being the most trustworthy, followed by traditional media, and with social media being perceived as the least trustworthy. However, this is the only research of which the authors are aware that compares all three sources within the same study. Additionally, respondents in this study rated traditional media as slightly more credible and valuable than did participants in other academic studies, indicating a potential difference between business managers and the general public.

Assuming rates of use provide some indication of relative value to the reader, from a general consumption standpoint business leaders' use of "social media" overall hovers around occasionally (represented by a mean of 2.0 in Table III), just below monthly magazines. Newspapers (print and online) settle between "Once a week," and "A few times weekly," with local television and radio closest to daily usage at 3.48. Considering the frequency of updates for social media, one might expect usage to be more frequent for those who use it at all. Even among users of these channels, daily use was reported by less than 25 percent of respondents in these categories, compared to local broadcast media which was closer to 40 percent.

Survey participants appear to perceive "social media" channels as lack luster on the whole. Certainly there were pockets of slightly higher opinions regarding social media tools, but these were just as likely to be among middle aged or older groups as with those earlier in their careers. For the most part, the findings were in parallel with the mainstream audience research cited earlier.

\section{Discussion}

Even though practitioners embrace new media and feel perceived benefits from its implementation in raising their own power and credibility, senior managers remain generally slow to accept engagement and legitimization of social media.

\begin{tabular}{|c|c|c|c|c|c|c|}
\hline & Wilks' $\lambda$ & $F$ & $\mathrm{df}$ & Sig. & Effect size $\left(\eta_{p}{ }^{2}\right)$ & \\
\hline \multicolumn{7}{|l|}{ Multivariate } \\
\hline $\begin{array}{l}\text { Univariate } \\
\text { InfoSource } \\
\text { Trust } \\
\text { InfoValue }\end{array}$ & & $\begin{array}{l}923.752 \\
831.723\end{array}$ & $\begin{array}{l}2,1540 \\
2,1540\end{array}$ & $\begin{array}{l}0.000^{* * * *} \\
0.000^{* * * *}\end{array}$ & $\begin{array}{l}0.545 \\
0.519\end{array}$ & $\begin{array}{r}\text { Table II. } \\
\text { Multivariate analysis } \\
\text { of variance: do trust } \\
\text { and information } \\
\text { value vary by }\end{array}$ \\
\hline \multicolumn{6}{|c|}{ Notes: $n=523 . * * *$ Correlation is significant at the 0.001 level (two-tailed) } & information source? \\
\hline
\end{tabular}

Anti-social media

281 


\begin{tabular}{|c|c|c|c|c|c|c|c|}
\hline $\begin{array}{l}\text { JCOM } \\
19,3\end{array}$ & Source & $\begin{array}{l}\text { Rarely/ } \\
\text { never }^{\mathrm{a}}\end{array}$ & Occasionally $^{\mathrm{a}}$ & $\begin{array}{c}\text { Once } \\
\text { weekly }^{\mathrm{a}}\end{array}$ & $\begin{array}{l}\text { A few times } \\
\text { weekly }^{\mathrm{a}}\end{array}$ & Daily $^{\mathrm{a}}$ & Mean $^{\mathrm{b}}$ \\
\hline \multirow{5}{*}{282} & LinkedIn & 208 & 123 & 58 & 48 & 50 & 2.20 \\
\hline & Blogs & 201 & 142 & 43 & 63 & 38 & 2.17 \\
\hline & Facebook & 276 & 86 & 30 & 51 & 44 & 1.98 \\
\hline & Twitter & 374 & 38 & 10 & 20 & 45 & 1.61 \\
\hline & Local television news & 78 & 77 & 36 & 125 & 171 & 3.48 \\
\hline \multirow{12}{*}{$\begin{array}{l}\text { Table III. } \\
\text { Frequency of } \\
\text { media usage }\end{array}$} & Local radio news & 75 & 77 & 42 & 107 & 175 & 3.48 \\
\hline & Local newspapers in print & 76 & 75 & 89 & 82 & 165 & 3.38 \\
\hline & National radio news & 79 & 94 & 44 & 109 & 153 & 3.34 \\
\hline & National television news & 85 & 92 & 48 & 129 & 133 & 3.27 \\
\hline & Local newspapers online & 72 & 115 & 76 & 105 & 119 & 3.17 \\
\hline & National newspapers online & 108 & 108 & 67 & 90 & 114 & 2.99 \\
\hline & National newspapers in print & 124 & 144 & 70 & 59 & 90 & 2.69 \\
\hline & Local magazines online & 111 & 140 & 99 & 101 & 36 & 2.61 \\
\hline & National magazines in print & 89 & 165 & 119 & 86 & 28 & 2.59 \\
\hline & Local magazines in print & 67 & 193 & 133 & 73 & 21 & 2.56 \\
\hline & National magazines online & 131 & 166 & 91 & 71 & 28 & 2.38 \\
\hline & \multicolumn{7}{|c|}{ Notes: a Number of respondents; ${ }^{b}$ rated on 1-5 Likert ( 5 being high) } \\
\hline
\end{tabular}

Arguably, CEOs in the foreseeable future must be appropriately versed in the advantages and disadvantages of platforms like Twitter as communication between company and consumers continues to trend toward an expectation of two-way conversation in these channels. A handful of socially active CEOs of Fortune 500 and Inc. 500 companies already demonstrated some possibilities of engaging on Twitter in a meaningful way, even if the conversation so far has been predominantly one-sided. However, the number of engaged CEOs remains a minority.

Assuming that senior managers in our study represent their peers across the country, the low level of confidence in the content of social media cannot help the evolution of executive engagement with channels like Twitter. Why would an executive want to join voices that are personally viewed as less than credible? Certainly the egos of certain individual CEOs break from this thought, but these voices appear not only to be outliers in their engagement with Twitter, but also in the level of opinion infused into tweets. In any case, social media has grown in no small part because of the two-way nature of the communication it provides. Whether engaged in public or even internal social media platforms at corporations, prima facie disconnect exists between the core value of these channels and their implementation by senior executives.

An additional contributor to this disconnect Christensen (1997) characterized as "auto-communication". This form of corporate messaging and activity is typified by an organization's leadership and communication practitioners becoming so enamored with the symbolism and messages that it continually reinforces its own assumptions, regardless of engaging in dialogue with stakeholders. This has been more recently documented in the area of corporate social responsibility (CSR), where proactive CSR image building had such a seductive effect on the organization that it ultimately inhibited team members from recognizing lapses in CSR work (Hagen, 2008). Social media has the potential to magnify the effects of "auto-communicative" messaging, particularly in organizations that attempt to actively moderate the online voices of employees. Further, one might assume that additional transparency in "CEO" presence and other corporate presence in social media will serendipitously find a trajectory away from these negative 
behaviors if releasing the reigns and engaging in real dialogue with stakeholders. Further research is needed to validate this assumption, but necessary in any case.

An additional point of disparity between the current usage of social media by corporate executives and the core premise of the media stems from the fact that CEOs, with some exceptions, appear to generally be using more formal language than is predominant on Twitter. This begs the question: Does the use of formal language and dominance of "corporate" content diminish the positive perception of CEO tweets because this style does not conform to the norm of the channel? Or is it accepted as an expected component of the "business" voice amid the social chatter? If so, does that expectation also assume a one-way conversation, and can that assumption represent an opportunity for the executive who genuinely engages a conversation in the space? Addressing these questions will require significant effort and can only be truly relevant if research is conducted on a much broader scale.

At bare minimum, the one-way tone of CEO tweets at the most prestigious firms in the USA suggests that the level of empowerment of communication advisors in these firms may be limited, if one considers the findings of Smith and Place (2013) to be true. Their work revealed a clear sense of empowerment among the sample of practitioners from significantly smaller organizations, particularly as it related to social media. Since their work indicated increased power and visibility through expertise in, and particularly measurement of social media, one may speculate that the value of these factors have not fully integrated into the culture of the Fortune and Inc. 500s.

This work comes to conclusions similar to those of Pettigrew and Reber (2010) who studied Fortune 500 web communication with journalists through online press rooms:

It is hoped that Fortune 500 companies would be leaders in making use of newer technologies and communication techniques, although that may, in fact, not be the reality. A study of smaller, newer, or more innovative companies might find that they are making use of a broader range of communication techniques via their Web sites to generate media awareness and coverage than the more established companies in this study .

It would also be prudent to continue to monitor the content and style of communication by senior executives in social channels like Twitter, as these technologies evolve and use trends from one platform to the next.

Finally, we posit that based on the second study cited in this work, the best future hope for social media credibility with executives will be mediocrity. This assumes that in the foreseeable future, the credibility of Twitter, Facebook and blogs improve to become at least equal to that of traditional media, which in our study proved to be slightly less than neutral. In particular, we would like to suggest that even if the slow adoption of Twitter by senior executives accelerates due to evolution of relevant measurable impacts or otherwise acknowledged best practices, in all likelihood the generalized credibility of the channel content (and other social media platforms) will not surpass that of traditional media. While this is merely speculative, we feel it to be an aspect of communication that deserves monitoring. This does not negate the value of social media any more than the diminishing prestige of traditional media would mean public relations practitioners might begin to ignore those channels. However, it logically suggests an uphill battle in persuading senior level leaders of the value of platforms like Twitter, increasing the necessity of making a solid business case for its use and not just offering a new megaphone for touting one-sided corporate messaging. 
$\mathrm{JCOM}$ 19,3

\section{Note}

1. For print business and consumer publications, BPA verifies all-paid, all-controlled, or any combination of paid and controlled circulation, reported in a single document, with each type of circulation broken out. Demographics may also be reported and audited.

\section{$284 \quad$ References}

Abdullah, Z. and Threadgold, T. (2008), "Towards the professionalisation of public relations in Malaysia: perception management and strategy development", Public Relations Review, Vol. 34 No. 3, pp. 285-287.

Barnes, N. and Mattson, E. (2010), "The Fortune 500 and social media: a longitudinal study of blogging and Twitter usage by America's largest companies", UMass, Dartmouth Center for Marketing Research, Dartmouth, MA.

CEO.Com/Domo (2012), "2012 CEO.com social CEO report”, available at: www.ceo.com/social-ceoreport/ (accessed January 29, 2013).

Christensen, L. (1997), "Marketing as auto-communication”, Consumption. Markets \& Culture, Vol. 1 No. 2, pp. 197-227.

Consumer Reports Web Watch (2005), "Leap of faith: using the internet despite the dangers", available at: www.consumerwebwatch.org/pdfs/princeton.pdf (accessed July 27, 2011).

Cook, C., Heath, F. and Thompson, R.L. (2000), "A meta-analysis of response rates in web- or internet-based surveys", Educational and Psychological Measurement, Vol. 60 No. 6, pp. 36-821.

Cycyota, C.S. and Harrison, D.A. (2002), "Enhancing survey response rates at the executive level: are employee- or consumer-level techniques effective?", Journal of Management, Vol. 28 No. 2, p. 169.

Diga, M. and Kelleher, T. (2009), "Social media use, perceptions of decision-making power, and public relations roles", Public Relations Review, Vol. 35 No. 4, pp. 440-442.

DiStaso, M., McCorkindale, T. and Wright, D. (2011), "How public relations executives perceive and measure the impact of social media in their organizations", Public Relations Review, Vol. 37 No. 3, pp. 325-328.

Doherty, C. (2005), “The public isn't buying press credibility”, Nieman Reports, Vol. 59 No. 2, pp. $47-48$.

Donadio, R. (2012), “Dear Friends': Pope takes to Twitter, with an assist”, New York Times, available at: www.nytimes.com/2012/12/13/world/europe/the-pope-now-on-twitter-postshis-first-message.html?_r=0 (accessed January 29, 2013).

Dutta, S. (2010), “What's your personal social media strategy?”, Harvard Business Review, Vol. 88 No. 11, pp. 127-130.

Edelman Trust Barometer (2013), "Edelman Trust Barometer", available at: www.edelman.com/ insights/intellectual-property/trust-2013/ (accessed February 1, 2013).

Edwards, L. (2006), "Rethinking power in public relations", Public Relations Review, Vol. 32 No. 3, pp. 229-231.

Freberg, K., Graham, K., McGaughey, K. and Freberg, L. (2011), "Who are the social media influencers? A study of public perceptions of personality", Public Relations Review, Vol. 37 No. 1, pp. 90-92.

Gaines-Ross, L. (2003), CEO Capital: A Guide to Building CEO Reputation and Company Success, Wiley, Hoboken, NJ.

Gilpin, D., Palazzolo, E. and Brody, N. (2010), "Socially mediated authenticity", Lournal of Communication Management, Vol. 14 No. 3, pp. 258-278. 
Hagen, D. (2008), "Seduced by their proactive image? On using auto communication to enhance CSR”, Corporate Reputation Review, Vol. 11 No. 2, pp. 130-144.

Jansen, B., Zhang, M., Sobel, K. and Chowdury, A. (2009), "Twitter power: tweets as electronic word of mouth", Journal of the American Society for Information and Technology, Vol. 60 No. 9, p. 20.

Johansen, W., Aggerholm, H.K. and Frandsen, F. (2012), "Entering new territory: a study of internal crisis management and crisis communication in organizations", Public Relations Review, Vol. 38 No. 2, pp. 270-279.

Johnson, T.J., Kaye, B.K., Bichard, S.L. and Wong, W.J. (2007), "Every blog has its day: politicallyinterested internet users' perceptions of blog credibility", Lournal of Computer-Mediated Communication, Vol. 13 No. 1, pp. 100-122.

Kent, M.L. (2008), "Critical analysis of blogging in public relations", Public Relations Review, Vol. 34 No. 1, pp. 32-40.

Kiousis, S. (2001), "Public trust or mistrust? Perceptions of media credibility in the information age", Mass Communication \& Societv, Vol. 4 No. 4, pp. 381-403.

Kwoh, L. and Korn, M. (2012), "140 characters of risk: some CEOs fear Twitter," Wall Street Journal, available at: http://online.wsj.com/article/SB10000872396390444083304578018423363962886. html?mod=e2tw (accessed January 29, 2013).

Laskin, A. (2012), "Public relations scales: advancing the excellence theory", Lournal of Communication Management, Vol. 16 No. 4, pp. 355-370.

Lovejoy, K., Waters, R., Saxton, G. (2012), "Engaging stakeholders through Twitter: how nonprofit organizations are getting more out of 140 characters or less", Public Relations Review, Vol. 38 No. 2, pp. 313-318.

Meng, J., Berger, B.K., Gower, K.K. and Heyman, W.C. (2012), "A test of excellent leadership in public relations: key qualities, valuable sources, and distinctive leadership perceptions", Iournal of Public Relations Research, Vol. 24 No. 1, pp. 18-36.

Pettigrew, J. and Reber, B. (2010), "The new dynamic in corporate media relations: how fortune 500 companies are using virtual press rooms to engage the press", Lournal of Public Relations Research, Vol. 22 No. 4, pp. 404-428.

Pew Research Center (2005), "Media: more voices, less credibility", available at: http:// pewresearch.org/assets/files/trends2005-media.pdf (accessed November 15, 2014).

Porter, L.V. and Sallot, L.M. (2005), "Web power: a survey of practitioners' world wide web use and their perceptions of its effects on their decision-making power", Public Relations Review, Vol. 31 No. 1, pp. 111-119.

Porter, L.V., Trammel, K.D., Chung, D. and Kim, E. (2007), "Blog power: examining the effects of practitioner blog use on power in public relations", Public Relations Review, Vol. 33 No. 1, pp. 92-95.

Roper, J. (2005), "Symmetrical communication: excellent public relations or a strategy for hegemony?”, Journal of Public Relations Research, Vol. 17 No. 1, pp. 69-86.

Rybako, S. and Seltzer, T. (2010), "Dialogic communication in 140 characters or less: how Fortune 500 companies engage stakeholders using Twitter", Public Relations Review, Vol. 36 No. 4, pp. 336-341.

Schmierbach, M. and Oeldorf-Hirsch, A. (2010), “A little bird told me, so I didn't believe it: Twitter, credibility, and issue perceptions", paper presented at the 93rd annual conference of the Association for Education in Journalism \& Mass Communication (AEJMC), Denver, CO, August 4-7.

Schmierbach, M. and Oeldorf-Hirsch, A. (2012), "A little bird told me, so I didn't believe it: Twitter, credibility, and issue perceptions", Communication Quarterly, Vol. 60 No. 3, pp. 317-337. 
JCOM 19,3

Sweetser, K.D., Porter, L.V., Chung, D.S. and Kim, E. (2008), "Credibility and the use of blogs among professionals in the communication industry", Lournalism \&Mass Communication Quarterly, Vol. 85 No. 1, pp. 169-185.

Tallapragada, M., Misaras, I.C., Burke, K. and Waters, R.D. (2012), "Identifying the best practices of media catching: a national survey of media relations practitioners", Public Relations Review, Vol. 38 No. 5, pp. 926-931.

Taylor, M. and Kent, M. (2010), "Anticipatory socialization in the use of social media in public relations: a content analysis of PRSA's public relations tactics", Public Relations Review, Vol. 36 No. 3, pp. 207-214.

Vorvoreanu, M. (2009), "Perceptions of corporations on Facebook: an analysis of Facebook social norms", Journal of New Communications Research, Vol. 4 No. 1, pp. 67-86.

Wasserman, T. (2013), "70\% of consumers trust brand recommendations from friends", Mashable, available at: http://mashable.com/2013/03/21/70-percent-brand-recommendations-friends/ (accessed April 1, 2013).

Waters, R.D. and Jamal, J.Y. (2011), "Tweet, tweet, tweet: a content analysis of nonprofit organizations' Twitter updates", Public Relations Review, Vol. 37 No. 3, pp. 321-324.

Westerman, D., Spence, P.R. and Van Der Heide, B. (2014), "Social media as information source: recency of updates and credibility of information", Lournal of Computer-Mediated Communication, Vol. 19 No. 2, pp. 171-183.

Wright, D.K. and Hinson, M.D. (2010), "An analysis of new communications media use in public relations: results of a five-year trend study", Public Relations Journal, Vol. 4 No. 2, pp. 1-27.

Xifra, J. and Grau, F. (2010), "Nanoblogging PR: the discourse on public relations in Twitter", Public Relations Review, Vol. 36 No. 2, pp. 171-174.

Yang, A. and Taylor, M. (2013), "The relationship between the professionalization of public relations, societal social capital and democracy: evidence from a cross-national study", Public Relations Review, Vol. 39 No. 4, pp. 257-270.

\section{Further reading}

Burt, R.S. (2000), “The network structure of social capital”, Research in Organizational Behavior, Vol. 22, pp. 345-423.

Edwards, L. (2011), "Rethinking power in public relations", Public Relations Review, Vol. 32 No. 3, pp. 229-231.

Ferlander, S. (2003), The Internet, Social Capital and Local Community, Department of Psychology, University of Sterling, Stirling.

Johnson, T.J. and Kaye, B.K. (2000), "Using is believing: the influence of reliance on the credibility of online political information among politically interested internet users", Journalism \& Mass Communication Quarterly, Vol. 77 No. 4, pp. 865-879.

Johnson, T.J. and Kaye, B.K. (2002), "Webelievability: a path model examining how convenience and reliance predict online credibility", Lournalism \& Mass Communication Quarterly, Vol. 79 No. 3, pp. 619-642. 
Levin, D.Z. and Cross, R. (2004), "The strength of weak ties you can trust: the mediating role of trust in effective knowledge transfer", Management Science, Vol. 50 No. 11, pp. 1477-1490.

Levin, D.Z., Cross, R. and Abrams, L.C. (2002), "The strength of weak ties you can trust: the mediating role of trust in effective knowledge transfer", Academy of Management Proceedings 2002, Vol. 2002 No. 1, pp. 1-7.

\section{Appendix}

\begin{tabular}{|c|c|c|c|c|c|c|c|}
\hline $\begin{array}{l}\text { Total } \\
\text { participants }\end{array}$ & 487 & & & & & & \\
\hline Gender & $\begin{array}{c}\mathrm{F} \\
(39 \%)\end{array}$ & $\begin{array}{c}\mathrm{M} \\
(61 \%)\end{array}$ & & & & & \\
\hline Age & $\begin{array}{l}<30 \\
(24 \%)\end{array}$ & $\begin{array}{l}30-39 \\
(12 \%)\end{array}$ & $\begin{array}{l}40-49 \\
(25 \%)\end{array}$ & $\begin{array}{l}50-59 \\
(25 \%)\end{array}$ & $\begin{array}{l}60< \\
(14 \%)\end{array}$ & & Table AI. \\
\hline Years in Sr mgt. & $\begin{array}{c}<5 \\
(23 \%)\end{array}$ & $\begin{array}{c}5-10 \\
(18 \%)\end{array}$ & $\begin{array}{l}11-20 \\
(22 \%)\end{array}$ & $\begin{array}{l}20< \\
(19 \%)\end{array}$ & N/A $(18 \%)$ & & $\begin{array}{l}\text { Descriptive statistics: } \\
\text { study } 2 \text { - "What }\end{array}$ \\
\hline Company size & $\begin{array}{l}1-10 \\
(27 \%)\end{array}$ & $\begin{array}{l}11-50 \\
(21 \%)\end{array}$ & $\begin{array}{l}51-100 \\
(10 \%)\end{array}$ & $\begin{array}{c}101-250 \\
(11 \%)\end{array}$ & $\begin{array}{c}251-500 \\
(7 \%)\end{array}$ & $\begin{array}{l}500< \\
(23 \%)\end{array}$ & $\begin{array}{r}\text { Business Thinks" } \\
\text { survey }\end{array}$ \\
\hline
\end{tabular}

\section{Corresponding author}

Dr Michael C. Porter can be contacted at: mcporter@stthomas.edu 